\title{
Macronutrients Omission in the Growth of Cotton, BRS Topázio Cultivar Grown in Nutritious Solution
}

\author{
Felipe Guedes De Souza1, Lucia Helena Garófalo Chaves $^{1 *}$, Allan Nunes Alves ${ }^{1}$, \\ Jorge Alves De Souza ${ }^{2}$ \\ ${ }^{1}$ Department of Agricultural Engineering, Federal University of Campina Grande, Paraiba State, Brazil \\ ${ }^{2}$ Department of Education, Federal University of Campina Grande, Paraiba State, Brazil \\ Email:felipeguedes.eng@gmail.com, *lhgarofalo@hotmail.com, all an.lnunes@gmail.com, jorgeas@ufcg.edu.br
}

How to cite this paper: Souza, F.G., Chaves, L.H.G., Alves, A.N. and Souza, J.A. (2017) Macronutrients Omission in the Growth of Cotton, BRS Topázio Cultivar Grown in Nutritious Solution. American Journal of Plant Sciences, 8, 2345-2357.

https://doi.org/10.4236/ajps.2017.810157

Received: August 6, 2017

Accepted: September 1, 2017

Published: September 4, 2017

Copyright $\odot 2017$ by authors and Scientific Research Publishing Inc. This work is licensed under the Creative Commons Attribution International License (CC BY 4.0).

http://creativecommons.org/licenses/by/4.0/

\begin{abstract}
With the objective to determine the probable causes of the appearance of abnormalities in BRS Topázio cotton plants, a greenhouse experiment was carried out per subtraction, in which nutrients were omitted: $\mathrm{N}, \mathrm{P}, \mathrm{K}, \mathrm{Ca}, \mathrm{Mg}$ and $\mathrm{S}$, totalizing 21 experimental units. The omission of $\mathrm{N}, \mathrm{P}, \mathrm{K}$ and $\mathrm{Ca}$ in the nutrient solution reduced the biometric characteristics of the cotton crop, with $\mathrm{K}$ and $\mathrm{Ca}$ being the most affected by these characteristics. The visual symptoms in cotton plants are seen with more severity in the lack of $\mathrm{K}, \mathrm{P}, \mathrm{K} \mathrm{Ca}$ and $\mathrm{Mg}$ elements. The omission of S did not affect the development of the plants.
\end{abstract}

\section{Keywords}

Gossypium hirsutum L., Nutritional Deficiency, Visual Diagnosis

\section{Introduction}

The herbaceous cotton (Gossypium hirsutum L.), annual crop, originating in Mexico and Central America [1], is among the ten main crops domesticated by man that stands out worldwide. In economic terms, it is the only crop that produces fiber, oil for human consumption and energy (biodiesel) [2]. The projection for the 2015/2016 crop puts Brazil as fifth producer, competing with China, India, the United States and Pakistan; in the same projection, Brazil ranks sixth as a consumer and the fourth largest exporter in the world [3].

Mineral nutrients are classified between macro and micronutrients according to the concentration found in plant tissues, being the macros: nitrogen $(\mathrm{N})$, phos- 
phorus $(\mathrm{P})$, potassium $(\mathrm{K})$, calcium $(\mathrm{Ca})$, magnesium $(\mathrm{Mg})$ and sulfur $(\mathrm{S})$ [4]. In order to achieve a good crop yield, it is necessary that the availability of the mineral nutrients is adequate, giving the plants an ideal quantity for their good development. However, the lack of any of these nutrients entails biochemical phenomena within plants that are expressed by characteristic symptoms. These symptoms are characterized in a quick way by the visual diagnosis, which consists in compare visually the appearance (color, size, shape) of the sample (plant, branches, leaves) with the pattern. This diagnosis identifies a plant with deficiency or excess of some nutrient, or excess of some chemical element.

However, in order to compare visually the plants, it is necessary to apply the subtraction diagnosis technique, which consists of conducting a nutrient solution trial where one of the treatments receives all the nutrients that the plant needs. The other treatments are a subtraction of each element, with others being supplied normally [5] [6].

A long time ago, several researchers have been discussing the mineral deficiencies in cotton crop, describing the nutritional disorders of the crop, the visual symptoms of the omission of the nutrients and the implications in the productivity. However, these descriptions differ in the behavior of different cultivars, which reflects in the manifestation and severity of the symptoms. Thus, a new cotton cultivar, BRS Topázio with light brown coloring fibers (colored cotton), may present different nutritional efficiencies, with greater or lesser response to certain nutrients. Therefore, the symptoms of nutritional deficiencies are important to obtain the diagnoses about the nutritional requirements of these plants and to monitor the effects of the omission of the nutrients in the nutrition of the same for the maximization of the economic return of the cotton activity [7] [8].

In this context, the present study tries to identify and describe the visual symptoms of macronutrient deficiencies, as well as to determine biometric characteristics of the cotton crop, due to the omission of nutrients.

\section{Material and Methods}

The experiment was carried out under greenhouse conditions of the Department of Agricultural Engineering of the Federal University of Campina Grande, from June to August of 2016, with cotton plants of the cultivar BRS Topázio.

The statistical design was completely randomized, with seven treatments and three replicates, as follows: T1-complete solution (control) according to [9], $\mathrm{T} 2$-nutritive solution with omission of nitrogen $(\mathrm{N})$, T3-nutritive solution with omission of phosphorus (P), T4-nutritive solution with omission of potassium (K), T5-nutritive solution with omission of calcium (Ca), T6-nutritive solution with omission of magnesium (Mg), T7-nutritive solution with omission of sulfur (S), totalizing 21 experimental units, containing in each experimental unit a cotton plant.

The stock nutrient solutions were prepared with P.A. reagent and deionized 
water. During the whole experiment, $\mathrm{pH}$ and electrical conductivity (EC) measurements were taken to control them, always maintaining $\mathrm{pHs}$ in the range of 6.0 to 7.0 and EC around $2.5 \mathrm{dS} \cdot \mathrm{cm}^{-1}$.

The cotton plants, BRS Topázio cultivar, used in the experiment, were obtained via seeds and germinated in phenolic sponges conditioned in a plastic container (disposable cups) with a capacity of $50 \mathrm{ml}$ containing deionized water until the surface of the foam.

Six days after germination, the seedlings were transferred to the complete nutrient solution of Hoagland and Arnon [9], with $10 \%$ of their ionic strength for an adaptation, which remained under constant aeration until the final stage of pot experimentation. After this adaptation period, the plants were transplanted to one liter pots and treatments were applied under the missing element technique. The nutrient solutions were changed weekly and their ionic strength increased gradually until reaching $100 \%$. The pots were capped with styrofoam with a hole in the center of them for the fixation of the crops and another hole in the end for the entrance of air.

The evaluations of biometric characteristics, such as plant height, stem diameter and number of leaves, were done every 10 days. After 50 days after sowing (DAS) the plants were harvested and placed in an air circulation oven, at a temperature of $65^{\circ} \mathrm{C}-70^{\circ} \mathrm{C}$, until the material had a constant mass. Subsequently, the material was weighed on a precision scale for the determination of dry mass. Visual deficiency symptoms were recorded by photographs and described throughout the experimental period. The data were submitted to analysis of variance and comparison of means, using the Turkey test at the level of 1 (\%) probability, applying the SISVAR software [10].

\section{Results and Discussion}

\subsection{Description of Visual Symptoms}

The absence of nitrogen in the nutrient solution affected significantly the cotton plants, identifying, at the beginning of the plant growth, a change of coloration in the shade of green, mainly in the older leaves corroborating [11]. According to this author, the nitrogen deficiency in the plants results in the collapse of the chloroplasts, thus, occurring a decline in the levels of chlorophyll. As nitrogen deficiency was maintained for all fifty days of experimentation, the loss of light green color of older leaves became yellowish, probably due to the low availability of chlorophyll to the plant (Figure 1(d)).

Similar symptoms were observed by [12] Cruz et al. (1983), in sunflower plants of the line LA 1, under greenhouse conditions, but observed at the beginning of the chapter formation until flowering. Souza et al. [13] (2016), working with the sesame crop of G3 cultivar, in greenhouse, also observed chlorosis symptoms at the beginning of plant development.

The nitrogen besides being part of the structure of amino acids, proteins, nitrogenous bases, nucleic acids, enzymes, coenzymes, vitamins, pigments and 




(a)

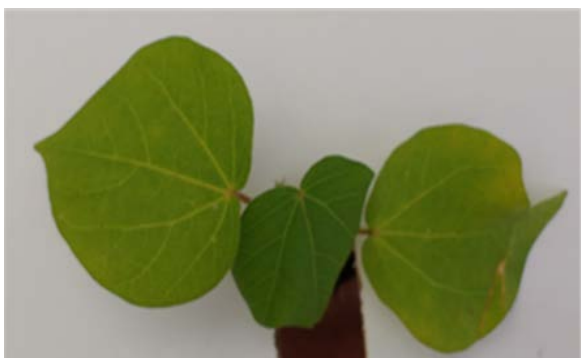

(c)

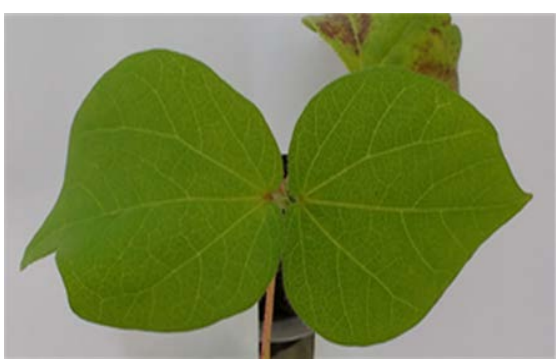

(b)

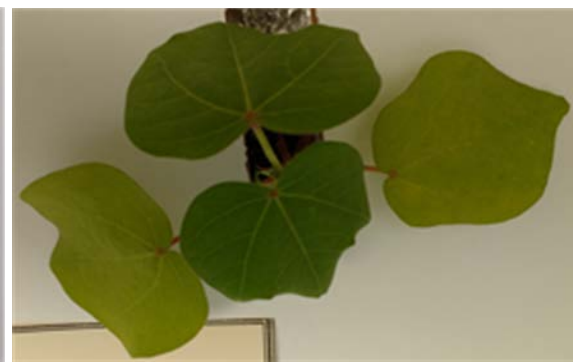

(d)

Figure 1. Visual symptoms of nitrogen deficiency in cotton leaves, BRS Topázio, at twenty (a), thirty (b), forty (c) and fifty days (d) of the experimental period.

byproducts, it participates in processes such as ionic absorption, photosynthesis, respiration, multiplication and cellular differentiation [14]. Therefore, the absence of nitrogen affected all the growth of the cotton plants during the fifty days of experiment.

Phosphorus, like nitrogen, has the mechanism of redistributing, through its mobility, one organ from the plant to another, especially from the older leaves towards the younger leaves. Therefore, the deficiency symptoms of this element occur predominantly in the older leaves compared to the younger leaves.

The symptoms caused by the absence of phosphorus in the nutrient solution for the development of the cotton crop were identified at the beginning of the growth of the plants presenting green-tanned chlorosis parallel to the veins of the leaves in their initial stage evolving to necrosis from the extremities to the leaf blade.

The older leaves had brownish-brown necrotic spots, causing their death at forty days after sowing; In addition, it can be observed throughout the experimental period that the leaves wilted and became wrinkled (Figure 2).

The deficiency of phosphorus can produce anthocyanins in excess, giving the leaves purplish staining, which did not occur in cotton plants [15]. The symptoms of potassium deficiency in cotton plants appeared after the twenty DAS, where the plants presented in their leaves, initially a process of overlapping the leaves with the same turning towards the stem, followed by chlorosis. These symptoms are observed first in older leaves, because this nutrient is very mobile in the phloem, so when there is a deficiency of this element, the potassium reserve that exists is moved to the younger leaves because they require a greater demand for develop [16] [17]. This was confirmed in the present work, that is, 


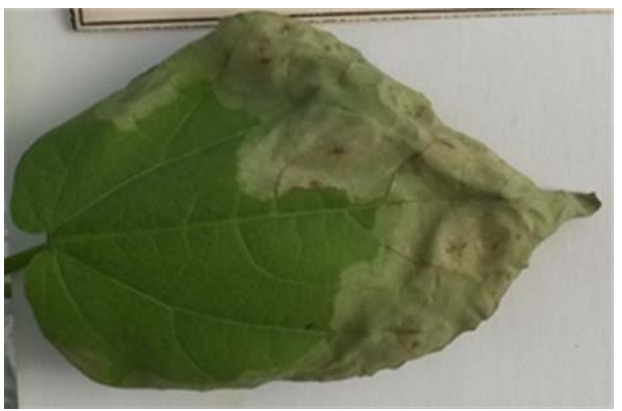

(a)

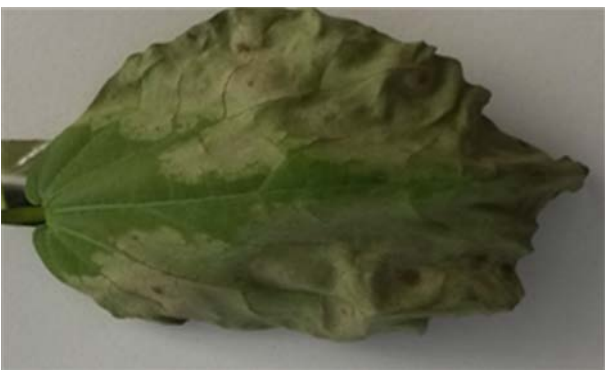

(c)

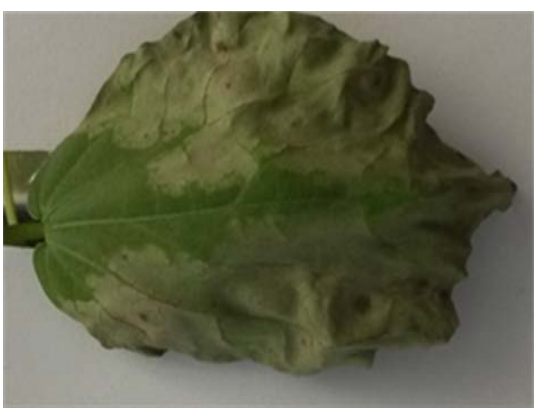

(b)

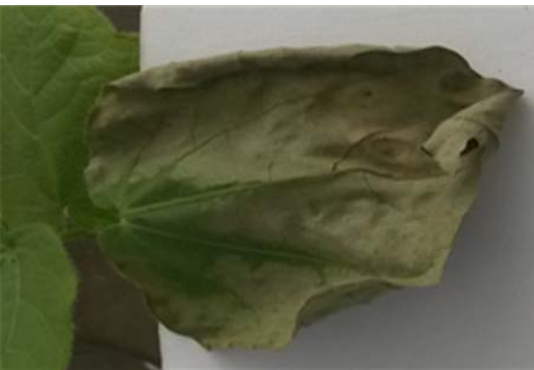

(d)

Figure 2. Visual symptoms of phosphorus deficiency in cotton leaves, BRS Topázio, at twenty (a), thirty (b), forty (c) and fifty days (d) of the experimental period.

the lack of potassium in the nutritive solution aggravated the symptoms of the older leaves, occurring a necrosis that began at the tips and margins evolving towards the central vein. It was also possible to observe the older leaves wilted and yellow (Figure $3(\mathrm{~d})$ ).

Prado and Leal [18] when submitting sunflower to potassium deficiency observed similar results, where the deficiency favored the appearance of chlorosis in the leaves, especially in the margins and tips of the leaves. Ferreira et al. [19] described the same symptoms when the castor bean plant underwent potassium deficiency in a greenhouse experiment.

Initially, the absence of calcium in the nutrient solution caused chlorosis in the young leaves of the cotton plants, with their greenish veins and absence of necrosis on the leaf margins, showing shading in the leaf limb and shortening of the internodes (Figure 4). These symptoms occur because calcium participates in the synthesis of the cell wall, in particular in the middle lamella separating the cells in division [15]. With the continuity of this absence, in some leaves began to appear symptoms of internerval necrosis. In the abaxial region some leaves showed a reddish or slightly purplish color, while in the upper part of the plant appeared chlorosis and a yellow mottling. Another characteristic symptom of calcium omission is the death of the hands, was noticed after the fifteen days of the experiment, observed in Figure 4(d).

Calcium deficiency may cause a petiole collapse, yellowing of its margins and wilting of younger leaves, and these symptoms have also been identified throughout this experiment in the cotton crop [20]. 


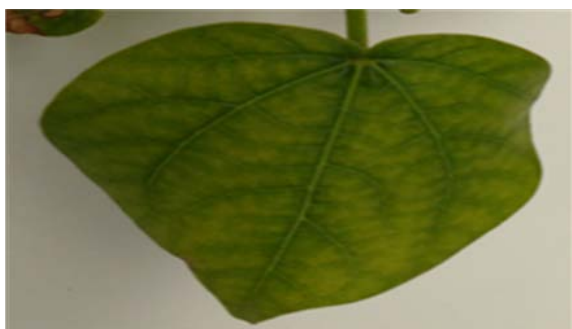

(a)

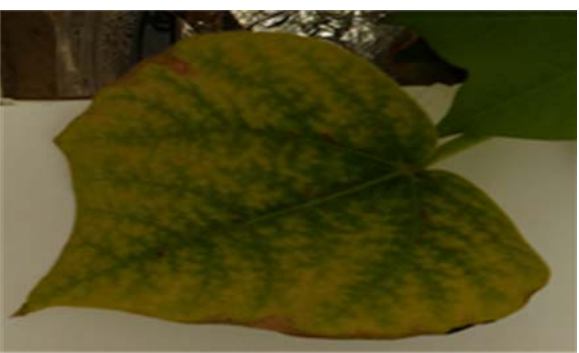

(c)

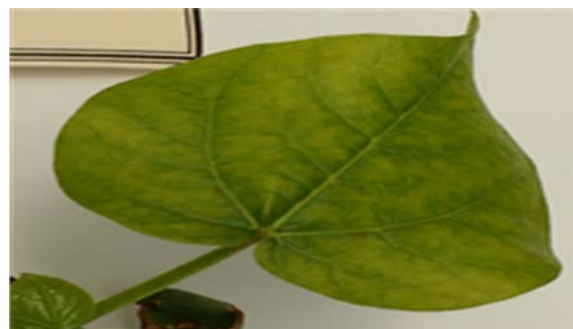

(b)

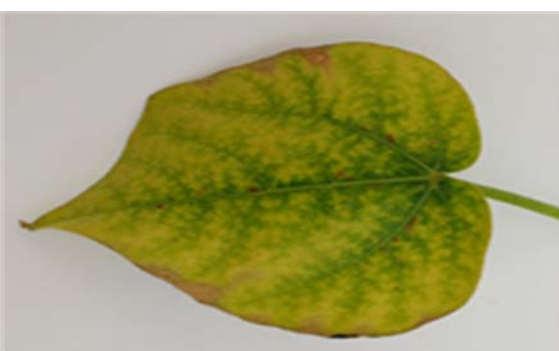

(d)

Figure 3. Visual symptoms of potassium deficiency in cotton leaves, BRS Topázio, at twenty (a), thirty (b), forty (c) and fifty days (d) of the experimental period.

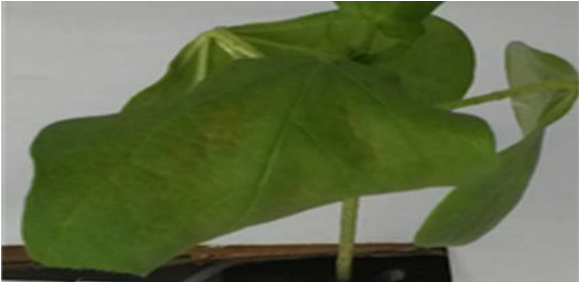

(a)

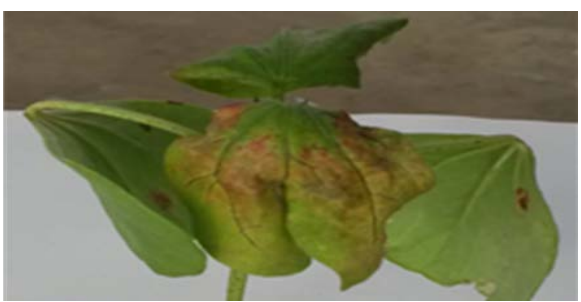

(c)

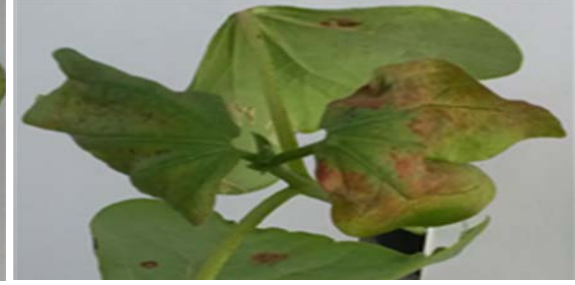

(b)

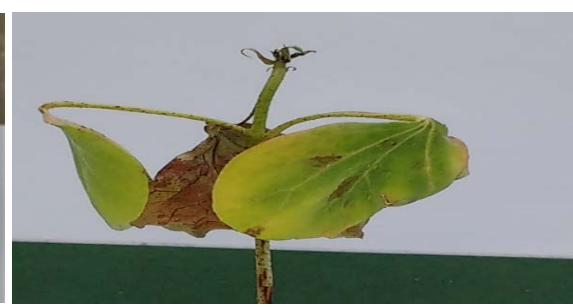

(d)

Figure 4. Visual symptoms of calcium deficiency in cotton leaves, BRS Topázio, at twenty (a), thirty (b), forty (c) and fifty days (d) of the experimental period.

Thirty DAS began to present the symptoms of magnesium deficiency in cotton plants, that is, internerval chlorosis in the medium leaves (Figure 5).

This is because the deficiency of this element, component of the chlorophyll molecule, reduces the chlorophyll pigment causing chlorosis in the leaves [21]. Over time, the symptoms appear in all the leaves, younger and older, showing white spots (Figure 5(b)), with borders wilting, the internal tissues fell and many leaves necrosed, as can be observed in Figure 5(d). This is because magnesium has a high mobility for the newer regions of active growth [22], very different from what we have seen in relation to the nutrient calcium. 


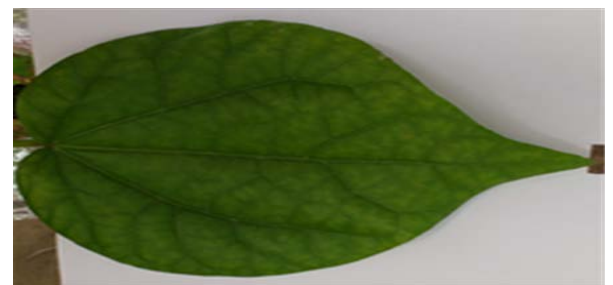

(a)

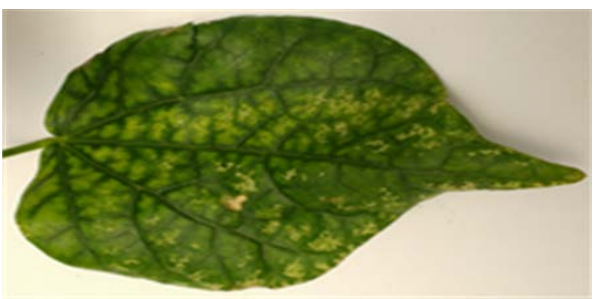

(c)

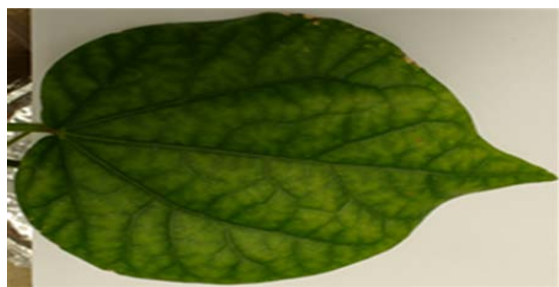

(b)

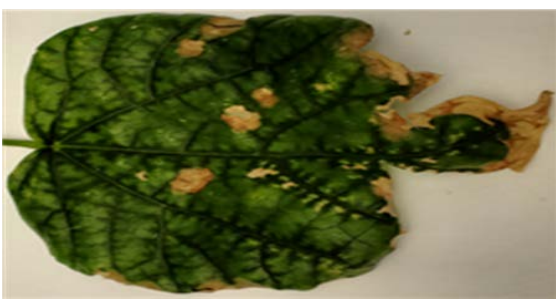

(d)

Figure 5. Visual symptoms of magnesium deficiency in cotton leaves, BRS Topázio, at twenty (a), thirty (b), forty (c) and fifty days (d) of the experimental period.

The symptoms of sulfur deficiency did not develop at any stage during the 50 experimental days, as seen in Figure 6.

Figure 7 shows cotton leaves, cultivar BRS Topazio, cultivated with complete nutrient solution, that is, leaves of the control plants, at 20; 30; 40 and 50 DAS.

\subsection{Biometric Characteristics Assessments}

The omission of macronutrients in the cotton crop showed significant differences in relation to growth, plant height $(\mathrm{cm})$, stem diameter $(\mathrm{mm})$, number of leaves, plant leaf area $(\mathrm{cm} 2)$ and dry matter $(\mathrm{g})$.

Plants submitted to nutrient omissions of nitrogen $(\mathrm{N})$, phosphorus $(\mathrm{P})$, potassium $(\mathrm{K})$ and calcium $(\mathrm{Ca})$, when compared to the complete treatment (solution with all nutrients), suffered the greatest reductions in plant height over the experimental period (50 days after sowing DAS) (Figure 8).

At 20 DAS, the omission of potassium and calcium caused a reduction in plant height of $78 \%$ and $64 \%$, respectively, when compared to plants submitted to complete treatment; in the last evaluation, 50 DAS, the difference was even major reaching to $86 \%$ and $80 \%$ for plants under omission of potassium and calcium, respectively. During the fifty days, the height of the plants cultivated with omission of potassium was increasing; however, with the omission of calcium the height of the plants did not vary (Figure 8).

The plants with the omission of nitrogen also had their growth affected, being verified to the 20 DAS reduction of plant height $57 \%$ inferior to the plants under nutrition with complete solution; however, the plants with omission of phosphorus were not affected significantly when compared as the plants of the complete solution; at 50 DAS the reduction of plant height with the omission of nitrogen and phosphorus corresponded to $72 \%$ and $65 \%$, respectively, when compared to the height of the plants grown with complete solution. Among treatments 


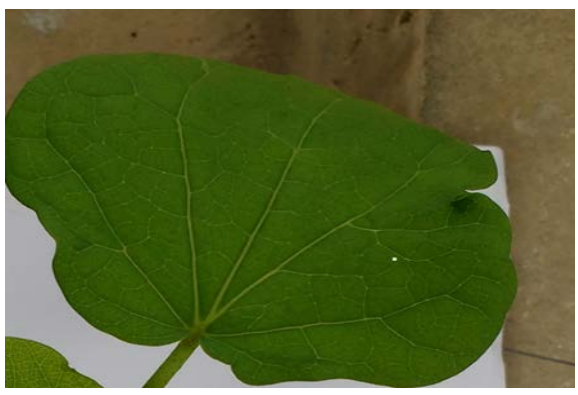

(a)

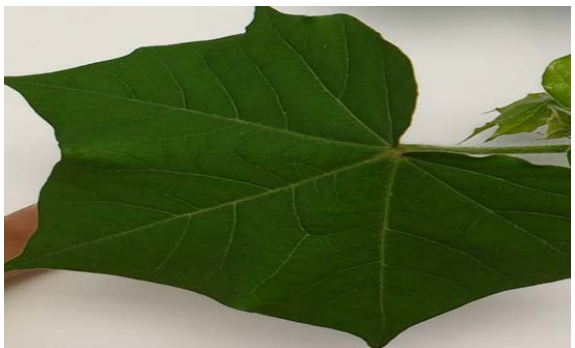

(c)

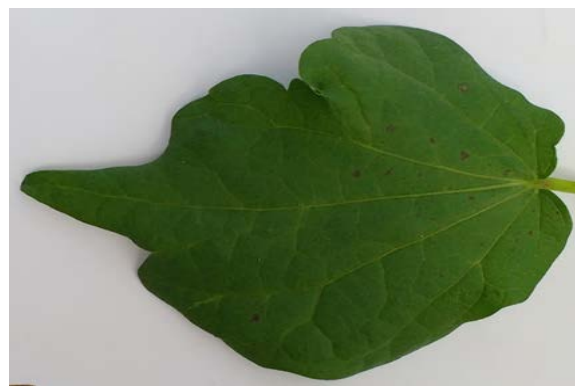

(b)

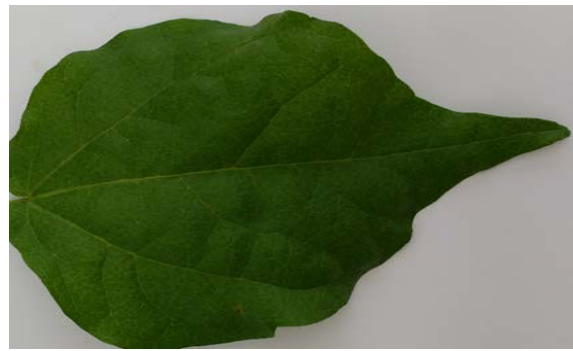

(d)

Figure 6. Visual symptoms of magnesium deficiency in cotton leaves, BRS Topázio, at twenty (a), thirty (b), forty (c) and fifty (d) days of the experimental period.

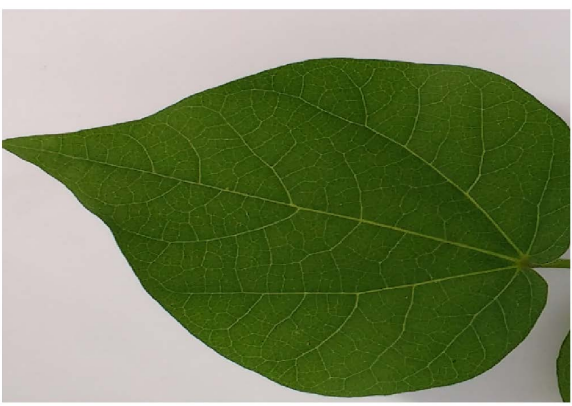

(a)

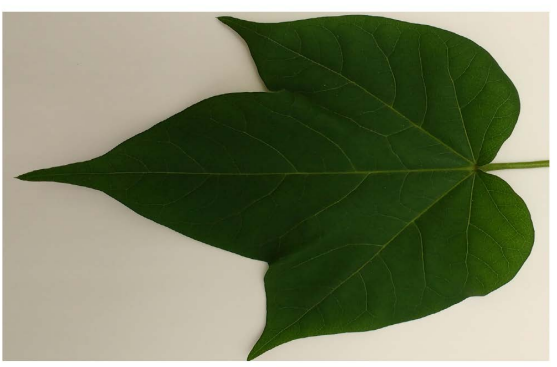

(c)

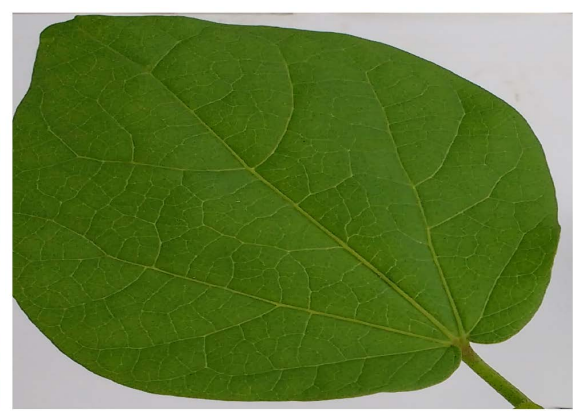

(b)

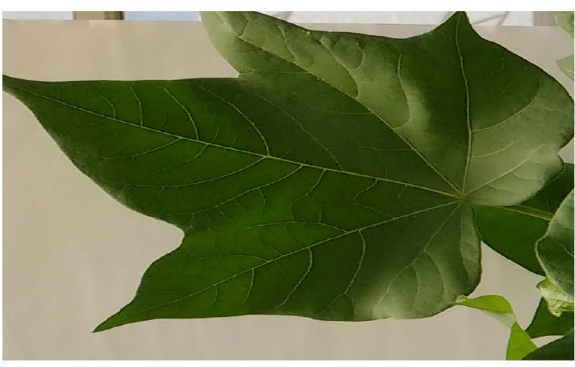

(d)

Figure 7. Cotton leaves, BRS Topazio, cultivated with complete nutritive solution at twenty (a), thirty (b), forty (c) and fifty (d) days of the experimental period.

after 20 DAS plants with nitrogen and phosphorus omission had a similar behavior in relation to plant height (Figure 8).

The omission of $\mathrm{N}$ in the mineral nutrition of plants can lead to a reduction of the growth of the crop, since this nutrient, besides being part of the structure of 


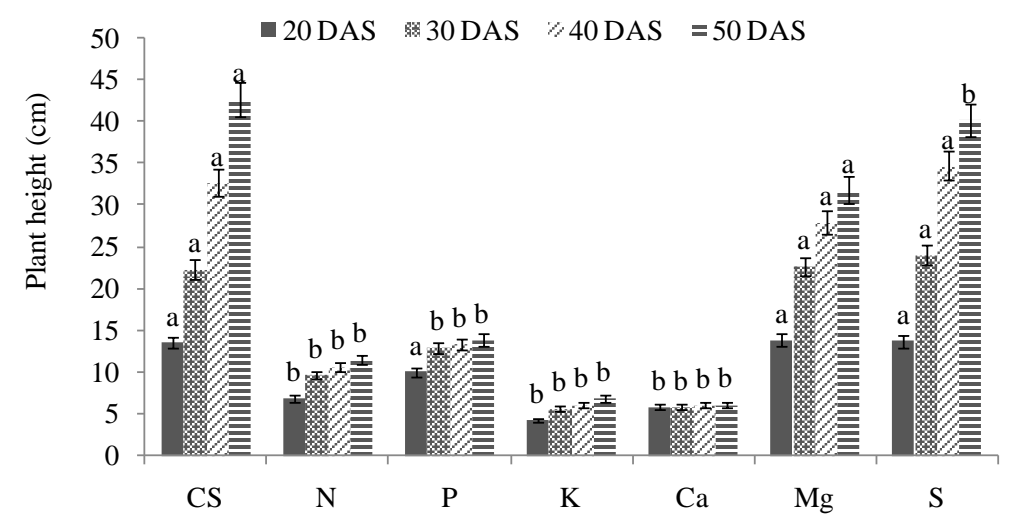

Figure 8. Plant height after 20,30, 40, and 50 DAS cultivated with complete solution (CS) and with the omission of nutrients of nitrogen $(\mathrm{N})$, phosphorus $(\mathrm{P})$, potassium $(\mathrm{K})$, calcium $(\mathrm{Ca})$, magnesium $(\mathrm{Mg})$ and sulfur $(\mathrm{S})$. Means (for each date) followed by the same letter do not differ from each other.

amino acids, proteins, nitrogen bases, nucleic acids, enzymes, coenzymes, pigments and byproducts, participates in processes such as ionic absorption, photosynthesis, respiration, multiplication and cellular differentiation, which interfere directly or indirectly in the development of the plant [14] [22]. This reduction in the height of the plants with omission of phosphorus can be explained by the decrease in the chemical energy supply produced in the chloroplast for the metabolic processes, for example, synthesis of proteins and nucleic acids [23].

The growth data obtained in this research are in agreement with those found by Prado and Leal [18], who studied the sunflower crop, also verified a lower growth when submitted to the omission of the nutrients calcium, potassium, nitrogen and phosphorus. Ferreira [24] studying the maize crop submitted to omission of macronutrients also verified a marked reduction in size when submitted to the omission of nutrients calcium, potassium, nitrogen and phosphorus. Souza et al. [13], investigating the omission of nitrogen and potassium in the sesame crop verified a significant reduction of plant height.

The stem diameters of cotton plants cultivated in nutrient solution with $\mathrm{N}, \mathrm{K}$ and $\mathrm{Ca}$ omission, when compared to the complete solution, were significantly affected during the whole experimental period, and in the 20 DAS there was a reduction in the stem diameters around $36 \%, 33 \%, 40 \%$, respectively. At 50 DAS, the reduction was around $85 \%, 80 \%$ and $82 \%$, respectively.

In the absence of $\mathrm{P}$, at $20 \mathrm{DAS}$, the stem diameter was not significantly affected, however, after this period, the stem diameters were reduced reaching a reduction of around $70 \%$ at 50 DAS (Figure 9).

The amounts of leaves in the cotton plants were significantly affected by the omission treatments of the nitrogen, phosphorus, potassium and calcium elements from the 30 DAS assessment (Figure 10).

Plants with deficiency of N, P, Ca, with the exception of $\mathrm{K}$ that obtained a reduction of $65 \%$ at 50 DAS, were significantly affected obtaining a reduction above $80 \%$ at 50 DAS when compared with the results found in plants with complete solution of nutrients. 


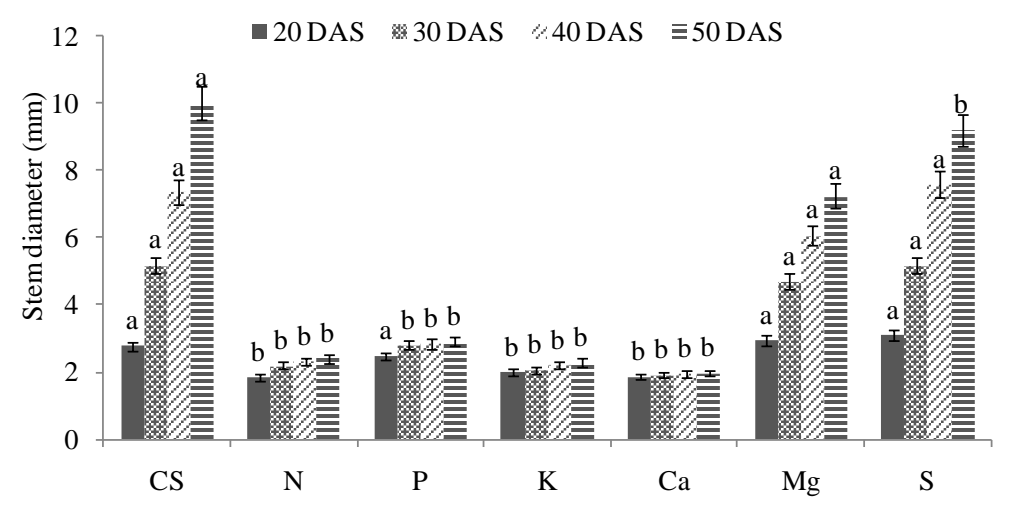

Figure 9. Stem diameter after the 20,30, 40, and 50 DAS cultivated with complete solution (CS) and with the omission of the nutrients nitrogen $(\mathrm{N})$, phosphorus $(\mathrm{P})$, potassium $(\mathrm{K})$, calcium $(\mathrm{Ca})$, magnesium $(\mathrm{Mg})$ and sulfur (S). Means (for each date) followed by the same letter do not differ from each other.

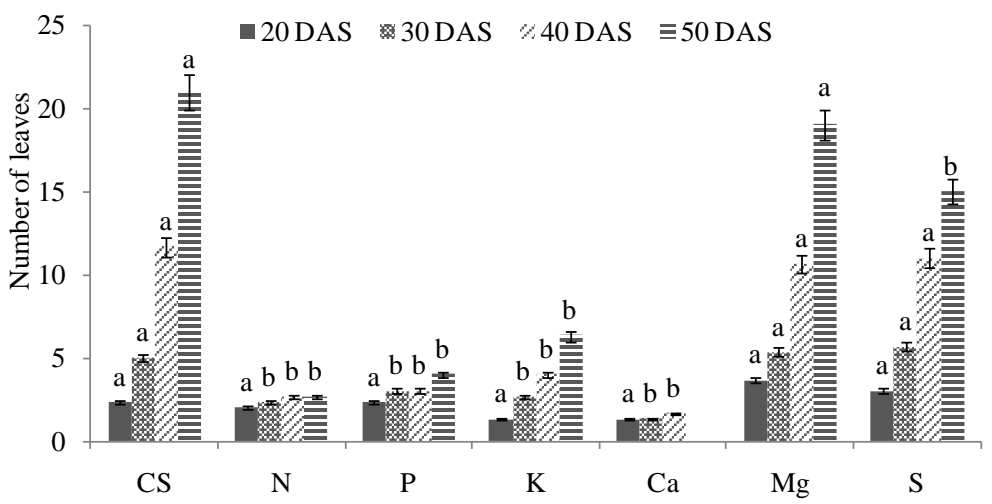

Figure 10. Number of leaves of cotton plants after 20,30, 40, and 50 DAS cultivated with complete solution (CS) and with the omission of nutrients nitrogen $(\mathrm{N})$, phosphorus $(\mathrm{P})$, potassium $(\mathrm{K})$, Calcium $(\mathrm{Ca})$, magnesium $(\mathrm{Mg})$ and sulfur (S). Means (for each date) followed by the same letter do not differ from each other.

Calcium is an essential macronutrient for plants [25], playing the important function of cell wall stabilization [26]. In addition, calcium ions and indoleacetic acid influence cell elongation and differentiation [27], and deficiency of this element may retard growth and cause meristem death [22]. In the present work, the omission of calcium in the nutrient solution affected the number of leaves in the cotton plants, probably because of the reasons mentioned above and because this element regulates and acts on plant phytohormones.

The reduction of the leaf area of cotton plants was over $90 \%$ depending on the treatments, that is, the nutrient solution without nitrogen, without potassium, without phosphorus and without calcium (Figure 11) corroborating Correia et al. [28], who observed a significant reduction of leaf area in peanut plants when nutrients $\mathrm{N}, \mathrm{P}, \mathrm{K}$ and Ca were omitted from the nutrient solution.

The omission of nutrients magnesium $(\mathrm{Mg})$ and sulfur $(\mathrm{S})$ showed no significant reduction in plant height (Figure 8), stem diameter (Figure 9), number of 


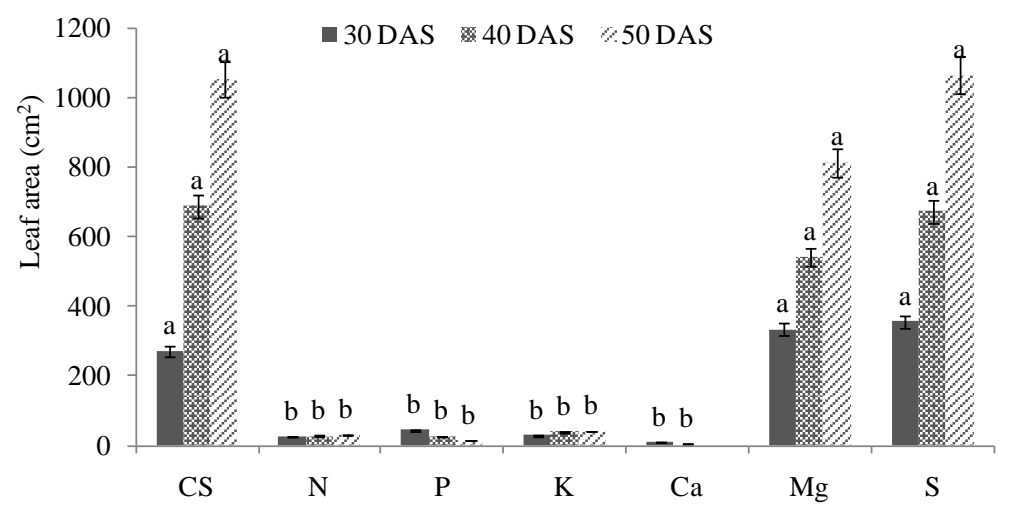

Figure 11. Leaf area of cotton plants after 20, 30, 40 and 50 DAS with complete solution (CS) and with the omission of nutrients nitrogen $(\mathrm{N})$, phosphorus $(\mathrm{P})$, potassium $(\mathrm{K})$, calcium $(\mathrm{N})$, nitrogen $(\mathrm{N})$, and nitrogen $(\mathrm{Ca})$, magnesium (Mg) and sulfur ( $\mathrm{S})$. Means (for each date) followed by the same letter do not differ from each other.

leaves (Figure 10) and leaf area (Figure 11) when compared with plants submitted to a complete solution corroborating Prado and Leal [18] and Santos et al. [29].

Although the biometric characteristics of the cotton plants cultivated in nutrient solution with the omission of the nutrients nitrogen, phosphorus, potassium and calcium differed significantly in relation to the complete solution, potassium and calcium nutrients were the ones that affected these characteristics, giving indications that these nutrients are more important in the growth and development of the cotton crop.

\section{Conclusions}

The omission of the nitrogen, phosphorus, potassium and calcium elements in the nutrient solution reduced the biometric characteristics of the cotton crop. These characteristics were most affected by potassium and calcium.

The visual symptoms in cotton plants were seen with greater severity in the absence of nitrogen, phosphorus, potassium, calcium and magnesium. The leaves with omission of $\mathrm{N}$ and $\mathrm{K}$ presented generalized chlorosis and chlorosis in the central vein, respectively, beginning in the older leaves. The absence of Ca presented chlorosis in the veins, starting with the younger leaves and shading in the leaf limbus. Leaves with omission of $\mathrm{P}$ presented green-tanned chlorosis parallel to the veins in their initial phase and evolving to necrosis that extended from the extremities to the leaf blade. The absence of $\mathrm{Mg}$ caused internerval chlorosis, and symptoms began on medium leaves.

The growth of the cotton crop was compromised when the plants were submitted to omission of macronutrients.

\section{References}

[1] Carvalho, L.P., Costa, J.N., Freire, E.C. and Farias, F.J.C. (2000) Adaptabilidade e estabilidade de linhagens de algodoeiro originários de materiais silvestres. Revista 
Ceres, 47, 303-310.

[2] Beltrão, N.E.M. and Azevedo, D.M.P. (2008) O Agronegócio do Algodão no Brasil. 2ed Edition, Embrapa Informação Tecnológica, Brasília, DF, 309 p.

[3] ICAC International Cotton Advisory Committee (2015) https://www.icac.org

[4] Waraich, E.A., Ahmad, R., Saifullah, Ashraf, M.Y. and Ehsanullah (2011) Role of Mineral Nutrition in Alleviation of Drought Stress in Plants. Australian Journal of Crop Science, 5, 764-777.

[5] Min Yan, W., Huan, W.L. and Ying, Y.X. (2008) Study of Common Symptoms of Element Deficiency and Concentration Changes of Nutrients in Composite Plants. Plant Nutrition and Fertilizer Science, 5, 1001-1007.

[6] Afrousheh, M., Ardalan, M. and Hokmabadi, H. (2010) Nutrient Deficiency Disorders in Pistaciavera Seedling Rootstock in Relation to Eco-Physiological, Biochemical Characteristics and Uptake Pattern of Nutrients. Scientia Horticulturae, 124, 141-148. https://doi.org/10.1016/j.scienta.2009.12.001

[7] Rosolem, C.A. and Bastos, G.B. (1997) Deficiências minerais no cultivar de algodão IAC. Bragantia, 56, 377-387. https://doi.org/10.1590/S0006-87051997000200017

[8] Vale, D.W., Prado, R.M., Avalhães, C.C. and Hojo, R.H. (2011) Omissão de macronutrientes na nutrição e no crescimento da cana-de-açúcar cultivada em solução nutritiva. RevistaBrasileira de CiênciasAgrárias, 6, 189-196.

https://doi.org/10.5039/agraria.v6i2a550

[9] Hoagland, D.R. and Arnon, D.I. (1950) The Water Culture Method for Growing Plants without Soil. California Agricultural Experiment Station, University of California, Berkeley. 32p.

[10] Ferreira, D.F. (2011) SISVAR: A Computer Statistical Analysis System. Ciência e Agrotecnologia, 35, 1039-1042. https://doi.org/10.1590/S1413-70542011000600001

[11] Malavolta, E. (2006) Manual de nutrição mineral de plantas. Agronômica Ceres Ltda, São Paulo, 631 p.

[12] Cruz, M.C.P., Ferreira, M.E. and Fernandes, N.G. (1983) Diagnose por subtração em girassol. Pesquisa Agropecuária Brasileira, 18, 1311-1315.

[13] Souza, F.G., Chaves, L.H.G. and Alves, A.N. (2016) Diagnose por subtração para deficiências de nitrogênio e potássio em gergelim cultivado com solução nutritiva. $R e-$ vista Verde de Agroecologia e Desenvolvimento Sustentável, 11, 171-176. https://doi.org/10.18378/rvads.v11i3.4363

[14] Malavolta, E., Vitti, G.C. and Oliveira, S. (1997) Avaliação do estado nutricional das plantas: Princípios e aplicações. Potafos, Piracicaba, 319 p.

[15] Taiz, L. and Zeiger, E. (2004) Fisiologia Vegetal. Artmed, Porto Alegre, 719 p.

[16] Fernandes, M.S. (2006) Nutrição Mineral de Plantas. Sociedade Brasileira de Ciência do Solo, $432 \mathrm{p}$.

[17] Yost, M.A., Russelle, M.P., Coulter, J.A., Sheaffer, C.C. and Kaiser, D.E. (2011) Potassium Management during the Rotation from Alfafa to Corn. Agronomy Journal, 103, 1785-1793. https://doi.org/10.2134/agronj2011.0183

[18] Prado, R.M. and Leal, R.M. (2006) Desordens nutricionais por deficiência em girassol var. Catissol-01. Pesquisa Agropecuária Tropical, 36, 187-193.

[19] Ferreira, G.B., Santos, A.C.M., Xavier, R.M., Ferreira, M.M.M., Severino, L.S. and Beltrão, N.E.M. (2004) Deficiência de fósforo e potássio na mamona (Ricinus communis L.): Descrição e efeito sobre o crescimento e a produção da cultura. I Congresso Brasileiro de Mamona: energia e sustentabilidade. 
[20] Malavolta, E., Gomes, P.F. and Alcarde, J.C. (2002) Adubos e adubações. Nobel, São Paulo, 187 p.

[21] Bottrill, D.E., Possingham, J.V. and Kriedemann, P.E. (1970) The Effect of Nutrient Deficiencies on Photosynthesis and Respiration in Spinach. Plant and Soil, 32, 424-438. https://doi.org/10.1007/BF01372881

[22] Marschner, P. (1995) Mineral Nutrition of Higher Plants. Academic Press, New York, $651 \mathrm{p}$.

[23] Mengel, K. and Kirkby, E.A. (2001) Principles of Plant Nutrition. Kluwer Academic Publishers, Dordrecht, 849 p. https://doi.org/10.1007/978-94-010-1009-2

[24] Ferreira, M.M.M. (2012) Sintomas de deficiência de macro e micronutrientes de plantas de milho híbrido BRS 1010. Revista Agro@mbiente On-Line, 6, 74-83. https://doi.org/10.18227/1982-8470ragro.v6i1.569

[25] Funk, J.L. and Amatangelo, K.L. (2013) Physiological Mechanisms Drive Differing Foliar Calcium Content in Ferns and Angiosperms. Oecologia, 173, 23-32. https://doi.org/10.1007/s00442-013-2591-1

[26] White, P.J. and Broadley, M.R. (2003) Calcium in Plants. Annals of Botany, 92, 487-511. https://doi.org/10.1093/aob/mcg164

[27] Bergmam, W. (1992) Nutritional Disorders of Plants. G. FischerVerlag, New York, $377 \mathrm{p}$.

[28] Correia, M.A.R., Prado, R.M., Almeida, T.B.F., Puga, A.P. and Barbosa, J.C. (2012) Avaliação da desordem nutricional de plantas de amendoim cultivadas em solução nutritiva suprimidas de macronutrientes. Scientia Agraria, 13, 21-28.

[29] Santos, A.R., Mattos, W.T., Almeida, A.A.S., Monteiro, F.A., Corrêa, B.D. and Gupta, U.C. (2004) Boron Nutrition and Yield of Alfafa Cultivar Crioula in Relation to Boron Supply. Scientia Agricola, 61, 496-500. https://doi.org/10.1590/S0103-90162004000500006

Scientific Research Publishing

\section{Submit or recommend next manuscript to SCIRP and we will provide best} service for you:

Accepting pre-submission inquiries through Email, Facebook, LinkedIn, Twitter, etc. A wide selection of journals (inclusive of 9 subjects, more than 200 journals)

Providing 24-hour high-quality service

User-friendly online submission system

Fair and swift peer-review system

Efficient typesetting and proofreading procedure

Display of the result of downloads and visits, as well as the number of cited articles

Maximum dissemination of your research work

Submit your manuscript at: http://papersubmission.scirp.org/

Or contact ajps@scirp.org 